\title{
Sosialisasi dan Edukasi Pencegahan Covid-19 Kepada Siswa Sekolah Dasar Negeri Cabi
}

\author{
Saifudin ${ }^{1}$, Nizar Hidayat ${ }^{2}$, Billy Rado ${ }^{3}$, Fathul Jannah ${ }^{4}$, Indrianto Rumapea ${ }^{5}$, Megawati ${ }^{6}$, \\ Muhammad Ardhi Faddakiri ${ }^{7}$, Nurul Jannah ${ }^{8}$, Ummi Husna ${ }^{9}$ \\ 1,2, Fakultas Ilmu Sosial dan Ilmu Politik, Universitas Lambung Mangkurat, \\ Jalan. H. Hassan Basry, Banjarmasin, Indonesia, \\ ${ }_{3,4,5,6,7,8,9}$ Mahasiswa Program Studi Ilmu Pemerintahan, Universitas Lambung Mangkurat, Fakultas Ilmu Sosial \\ dan Ilmu Politik, \\ Jalan. H. Hassan Basry, Banjarmasin, Indonesia, \\ *email: saifudin.fisip@ulm.ac.id \\ Diajukan \\ 29 Oktober 2021 \\ Informasi Artikel \\ Diterima \\ 20 November 2021 \\ Diterbitkan \\ 30 November 2021
}

\section{Keywords:}

Sosialisasi

Covid-19

Protokol Kesehatan

Pengabdian Masyarakat

\begin{abstract}
The education sector has implemented online learning, but now face-to-face learning can be carried out again by following the rules and complying with health protocols. SDN Cabi, Simpang Empat District, Banjar Regency also conducts face-to-face learning activities. The activity begins on August 30, 2021 which is carried out in stages. The method used is by using learning methods through mind mapping media, simulations or direct practice to students, and forming new habits systematically or in accordance with the steps of application starting from home, entering the school environment, and leaving the school environment. This can become a habit for students and is more organized or systematic. The material presented consists of: (1) how to wash hands properly and correctly, and (2) provide explanations accompanied by posters about the importance of complying with the implementation of $6 \mathrm{M}$, namely maintaining distance, wearing masks, washing hands, avoiding crowds, reducing mobility, and avoiding eating together.
\end{abstract}

\begin{abstract}
ABSTRAK
Selama ini, bidang pendidikan menerapkan pembelajaran secara daring, namun sekarang pembelajaran secara tatap muka dapat dilaksanakan kembali dengan tetap mengikuti aturan dan mematuhi protokol kesehatan. SDN Cabi Kecamatan Simpang Empat Kabupaten Banjar juga melakukan kegiatan belajar tatap muka. Kegiatan tersebut dimulai pada tanggal 30 Agustus 2021 yang dilakukan secara bertahap. Metode yang digunakan ialah dengan menggunakan metode pembelajaran melalui media mind mapping, simulasi atau praktik langsung ke siswa, dan membentuk pembiasaan baru secara sistematis atau sesuai dengan langkah penerapan mulai dari rumah, memasuki lingkungan sekolah, dan keluar dari lingkungan sekolah. Hal demikian dapat menjadi pembiasaan bagi siswa dan lebih teratur atau tersistem. Adapun materi yang disampaikan terdiri dari: (1) cara mencuci tangan yang baik dan benar, dan (2) memberikan penjelasan disertai poster tentang pentingnya mematuhi pemberlakuan $6 \mathrm{M}$, yaitu menjaga jarak, memakai masker, mencuci tangan, menghindari kerumunan, mengurangi mobilitas, dan menghindari makan bersama.
\end{abstract}

\section{Copyright and License:}

Authors retain copyright and grant the journal right of first publication with the work simultaneously licensed under a Creative Commons Attribution 4.0 International License that allows others to share the work with an acknowledgment of the work's authorship and initial publication in this journal. 


\section{PENDAHULUAN}

Penyakit virus corona (COVID-19) adalah penyakit menular yang disebabkan oleh virus SARS-CoV-2. Indonesia merupakan salah satu negara yang mana pada saat ini masuk dalam daftar penyebaran virus Covid-19 yang dimulai dari awal Maret 2020. Penyebaran virus Covid-19 ini terus bertambah dan berdampak pada berbagai sektor seperti sektor Pendidikan, perekonomian, pariswisata, dan sebagainya. Bertambah kasus tersebut mengharuskan pemerintah untuk menanggulangi dan mengatasi. Peran masyarakat juga diperlukan agar dapat memutus rantai penyebaran Covid-19 yang makin bertambah dengan cara menghormati dan mengikuti segala anjuran dari pemerintah. Menurut instruksi presiden, Nomor 6 Tahun 2020 tentang Peningkatan Protokol Kesehatan dalam Pencegahan dan Pengendalian Covid-19 upaya tersebut terus dilakukan sebagai bentuk dari kesungguhan pemerintah dalam mencegah bertambahnya kasus virus Covid-19.

Pemerintah dari sektor pendidikan melalui Kementerian Pendidikan dan Kebudayaan telah menegaskan bahwa seluruh sekolah wajib membuka pembelajaran tatap muka pada Juli 2021. Keputusan tersebut diambil berdasarkan keputusan SKB 4 Menteri yang memberi rambu-rambu tentang sekolah tatap muka (Syindi Oktaviani R. Tolinggi, Febry Ramadani 2020:8). Hal tersebut pastinya menimbulkan pro dan kontra di kalangan masyarakat luas. (Yudi Umara, Mar'atun Hasanah 2020:4) Bagi kalangan masyarakat pro terhadap sekolah tatap muka, berita ini adalah suatu kabar baik bagi dunia pendidikan Indonesia, karena selama ini model pembelajaran jarak jauh dianggap kurang maksimal, sehingga berpengaruh buruk terhadap motivasi dan prestasi siswa. Sedangkan, bagi masyarakat yang kurang setuju dengan belajar tatap muka, melihat bahwa keputusan tersebut dinilai terlalu berani dan bisa membahayakan keselamatan tenaga pendidik dan kependidikan ataupun peserta didik, mengingat kasus Covid-19 yang belum terkendali dengan baik. Pelaksanaan pembelajaran tatap muka bisa mulai dilaksanakan dengan syarat wajib menaati protokol kesehatan secara ketat (Ibnu Darmawan 2020:193).

Berdasarkan SKB Menteri Pendidikan dan Kebudayaan tentang Paduan Penyelenggaraan Pembelajaran Pada Tahun Ajaran 2020/2021 di Masa Pandemi Corona Virus Disease 2019 (Kementerian Kesehatan Republik Indonesia 2020) bahwa pembelajaran tatap muka dapat dilaksanakan di wilayah zona hijau dengan ketentuan dapat memenuhi semua daftar periksa dan terasa siap, serta adanya persetujuan dari pemerintah daerah dan orang tua siswa. Satuan pendidikan yang berada pada zona hijau dan siap melaksanakan pembelajaran tatap muka, harus mematuhi dan menerapkan protokol kesehatan di antaranya: memakai masker, mencuci tangan, dan menjaga jarak, selama berada di lingkungan sekolah.

Siswa yang melaksanakan pembelajaran tatap muka ini, khususnya siswa di sekolah dasar perlu mendapat perhatian dan kehati-hatian dalam pelaksanaanya mengingat rentan usia yang masih dalam kategori kanak-kanak dimana sistem imunitas tubuh mereka yang belum kuat dibandingkan orang dewasa. Siswa sekolah dasar ini masih memerlukan bimbingan secara langsung dari guru, diberikan pemahaman dan pembiasaan terkait penerapan protokol kesehatan. Menurut IDAI, kasus Covid-19 pada anak hingga 18 Mei 2020 (Manonjaya \& Tasikmalaya, 2021) ada sebanyak 3.324 kasus, 129 anak berstatus PDP meninggal dunia, 584 kasus anak terkonfirmasi positif Covid-19. Tentu hal ini menjadi bahan pertimbangan dan pembelajaran bagi sekolah khususnya di sekolah dasar agar lebih mengutamakan kesehatan anak-anak. Segala aktivitas anak harus terpantau karena usia mereka, khususnya anak-anak yang masih sekolah dasar karena mereka lebih banyak menghabiskan aktivitasnya dalam kegiatan bermain dan interaksi sosial. Termasuk di SDN Cabi adalah salah satu sekolah yang melaksanakan pembelajaran tatap muka secara sistem shift. Pembelajaran tatap muka tersebut berlangsung dari tanggal 30 Agustus 2021. Seluruh siswa di SDN Cabi pastinya perlu diberikan edukasi dan eksekusi secara serius terkait penerapan protokol kesehatan, sehingga hal ini tidak hanya sekedar narasi berupa perintah penerapannya, namun memberikan pemahaman secara mendalam dan praktik kepada siswa sebagai bentuk kepedulian dan kesadaran dalam diri masingmasing siswa setelah mereka memahami maksud dan tujuan dari penerapan protokol kesehatan itu sendiri.

Menurut Notoatmojo, 2010 (Syah et al., 2020) perilaku seseorang dapat dipengaruhi oleh faktor-faktor seperti pengetahuan, sikap, motivasi, dan lingkungan. Sehingga melalui kegiatan ini dapat merubah perilaku siswa dalam membentuk kebiasaan baru dengan benar, terkait penerapan protokol kesehatan. Pengabdian yang telah dilakukan oleh (Anita et al., 2020) terkait penerapan protokol kesehatan, dengan memberikan pemahaman kepada orang tua siswa dalam mendampingi anak menerapkan protokol kesehatan serta pendampingan pembuatan alat atau wadah mencuci tangan, begitupun pada pengabdian yang telah dilakukan oleh (Wijanarko et al., 2021) terkait optimalisasi penerapan protokol kesehatan penanganan Covid-19 pada fase new normal melalui literasi media, dengan membuat papan media dalam mensosialisasikan penerapan protokol kesehatan. Sehingga kami bermaksud untuk mensosialisasikan dan memberikan penguatan edukasi penerapan protokol kesehatan kepada siswa melalui metode pengajaran melalui media mind mapping, 
simulasi atau praktik langsung ke siswa, dan membentuk pembiasaan baru secara sistematis atau sesuai dengan langkah penerapan mulai dari rumah, memasuki lingkungan sekolah, dan keluar dari lingkungan sekolah. Hal demikian dapat menjadi pembiasaan bagi siswa dan lebih teratur atau tersistem.

\section{METODE}

Sosialisasi dan edukasi pencegahan Covid-19 kepada siswa SDN Cabi bertujuan agar memberikan informasi kepada siswa SDN Cabi Kecamatan Simpang Empat Kabupaten Banjar terkait pencegahan Covid19 dan pentingnya menerapkan protokol kesehatan. Metode yang digunakan adalah metode pengajaran melalui media mind mapping, simulasi atau praktik langsung ke siswa, dan membentuk pembiasaan baru secara sistematis atau sesuai dengan langkah penerapan mulai dari rumah, memasuki lingkungan sekolah, dan keluar dari lingkungan sekolah. Sosialisasi ini dilaksanakan secara langsung kepada SDN Cabi agar dapat mengeksplorasikan ilmu pengetahuan yang mereka dapatkan dari sosialisasi tersebut. Adapun materi yang disampaikan dalam sosialisasi terdiri dari: (1) cara mencuci tangan yang baik dan benar, serta (2) memberikan penjelasan disertai poster tentang pentingnya mematuhi pemberlakuan $6 \mathrm{M}$, yaitu menjaga jarak, memakai masker, mencuci tangan, menghindari kerumunan, mengurangi mobilitas, dan menghindari makan bersama. Dengan adanya sosialisasi dan edukasi mengenai pencegahan Covid-19 ini diharapkan para siswa SDN Cabi dapat menerapkannya pada kehidupan sehari-hari.

\section{HASIL DAN PEMBAHASAN}

\section{Tahap Persiapan}

Menghadapi new normal saat ini, dalam penerapan adaptasi pembiasaan baru, siswa harus dilibatkan dalam membangun kesadaran dalam diri terkait penerapan protokol kesehatan, agar terbentuk kebiasaan baru dalam aktivitasnya yang didasari atas kemauan dan kesadaran masing- masing individu.

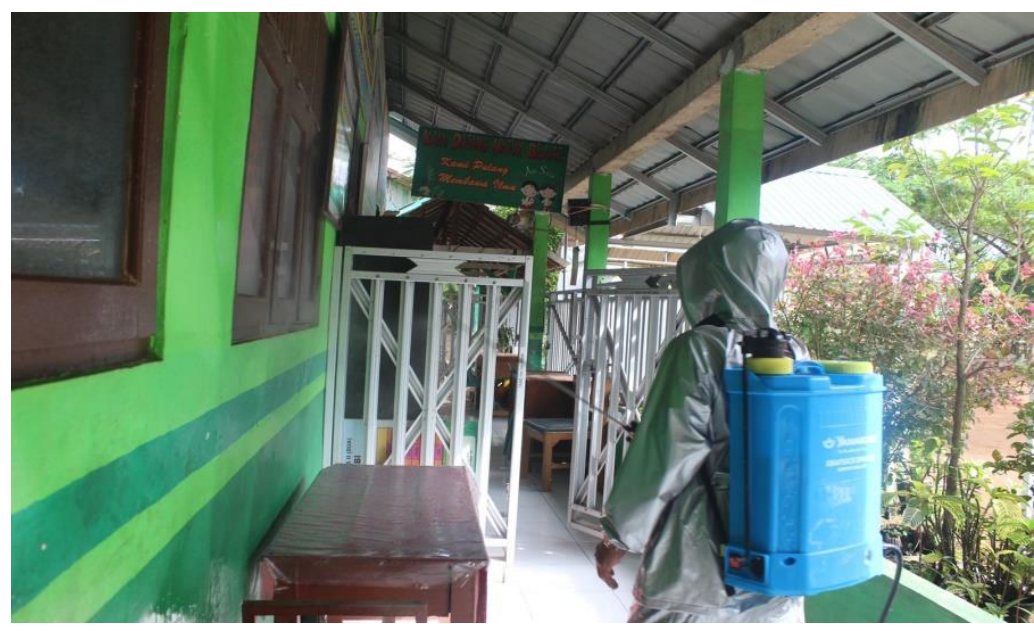

Gambar 1: Penyemprotan cairan disinfektan dilingkungan SDN Cabi

Kegiatan di atas adalah bentuk persiapan desa dan sekolah untuk memulai kegiatan belajar secara tatap muka dengan menerapkan protokol kesehatan yang ketat. Siswa sekolah dasar patut dilakukan pantauan secara ketat, mengingat aktivitas siswa disekolah dalam interaksi sosial, sehingga untuk mencegah penyebaran secara masif, pondasi utama yang perlu dikokohkan ada pada diri siswa itu sendiri. Sehingga diperlukan adanya penguatan edukasi menyambut new normal terkait penerapan protokol kesehatan di lingkungan sekolah.

\section{Tahap Pelaksanaan}

Sosialisasi terkait penguatan edukasi menyambut new normal terkait penerapan protokol kesehatan di lingkungan sekolah dilaksanakan di SDN Cabi setelah melakukan kesepakatan dengan pihak sekolah terkait waktu pelaksanaan yang tepat tanpa mengganggu aktivitas belajar siswa dan tetap menerapkan protokol kesehatan. Sehingga pelaksanaan sosialisasi dilaksanakan oleh masing- masing tim pada masing-masing kelas, guna menghindari penumpukan siswa pada satu ruangan. Kegiatan sosialisasi dihadiri oleh siswa dan masing-masing guru kelas dengan sistem penjadwalan secara bertahap atau shift. 


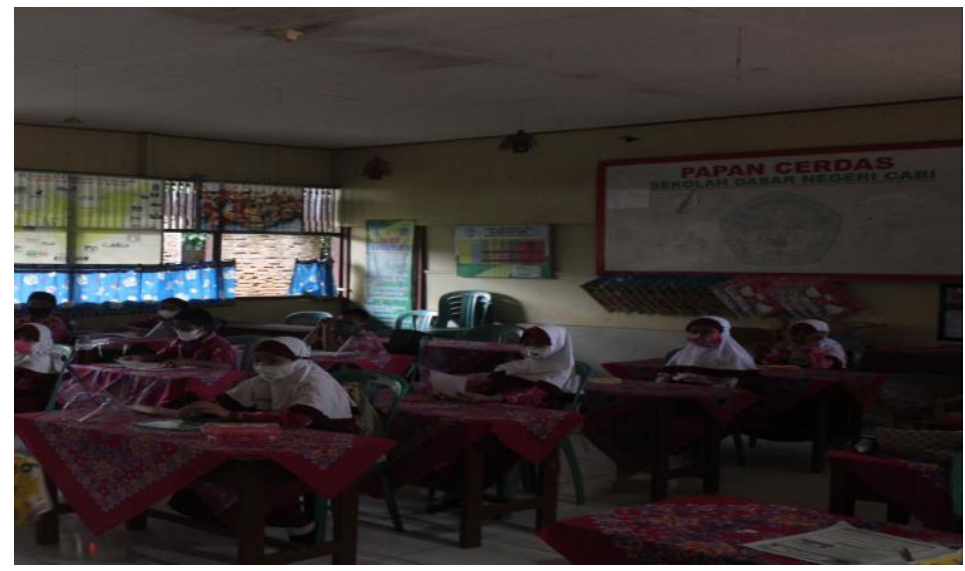

Gambar 2 : Kegiatan Sosialisasi Dan Edukasi Pencegahan Covid-19 Kepada Siswa/i SDN Cabi dengan media gambar dan praktik.

Kegiatan ini berlangsung selama Kamis 2 September 2021 dengan durasi waktu masing-masing 30 menit/shift. Setiap anggota pelaksana kegiatan PKM bertanggungjawab mensosialisasikan penyelenggaraan pembelajaran di kelas berdasarkan buku panduan pembelajaran pada tahun ajaran 2020/2021 (Kemdikbud, 2020), dengan ketentuan selama masa transisi, sekolah perlu memperhatikan tatap muka dengan jumlah hari dalam seminggu, jumlah jam dalam sehari, dan jumlah rombongan/shift. Selanjutnya memasuki masa new normal yang dapat melaksanakan kegiatan pembelajaran seperti sedia kala dengan tetap memperhatikan kondisi kesehatan dan keselamatan warga sekolah serta mematuhi protokol kesehatan dan wajib menutup kembali pembelajaran tatap muka di satuan pendidikan zona hijau apabila terindikasi tidak aman atau tingkat resiko daerahnya berubah. Sehingga dalam sosialisasi ini, disampaikan pula tata cara penerapan protokol kesehatan yang benar dan manfaatnya, diantanya tata cara mencuci tangan yang baik dan benar, dan memberikan penjelasan disertai poster tentang pentingnya mematuhi pemberlakuan $6 \mathrm{M}$, yaitu :

1. Mencuci Tangan Dengan Sabun

Rajin mencuci tangan mengurangi potensi terjadinya penularan virus covid-19. Penggunaan hand sanitizer berbahan dasar alkohol juga diperbolehkan. Namun, apabila ada akses untuk mencuci tangan, lebih baik mencuci tangan dengan sabun dan air mengalir.

2. Menggunakan Masker Bengan Benar

Masker berperan besar dalam menangkap droplet yang keluar dari mulut seseorang. Saat ini pemerintah menyarankan untuk menggunakan 2 masker agar potensi penularan berkurang.

3. Menjaga Jarak

Berikanlah jarak aman setidaknya 2 meter dengan orang lain untuk mencegah adanya perpindahan droplet dalam jarak dekat.

4. Menghindari Keramaian

Virus bisa saja hadir didalam tubuh seseorang tanpa pemberitahuan melalui gejala apapun sebelumnya. Jadi waspada dengan sekitar.

5. Menghindari Makan Bersama

Makan bersama apalagi dibarengi dengan berbicara sangat rawan terjadinya perpindahan droplet. Jadi, makan sendiri saja. Demi kesehatan diri sendiri dan orang lain.

6. Mengurangi Mobilitas

Apabila pekerjaan dapat dilakukan dari rumah, lebih baik dilakukan dari rumah. Keluar rumah hanya untuk kepentingan darurat. 


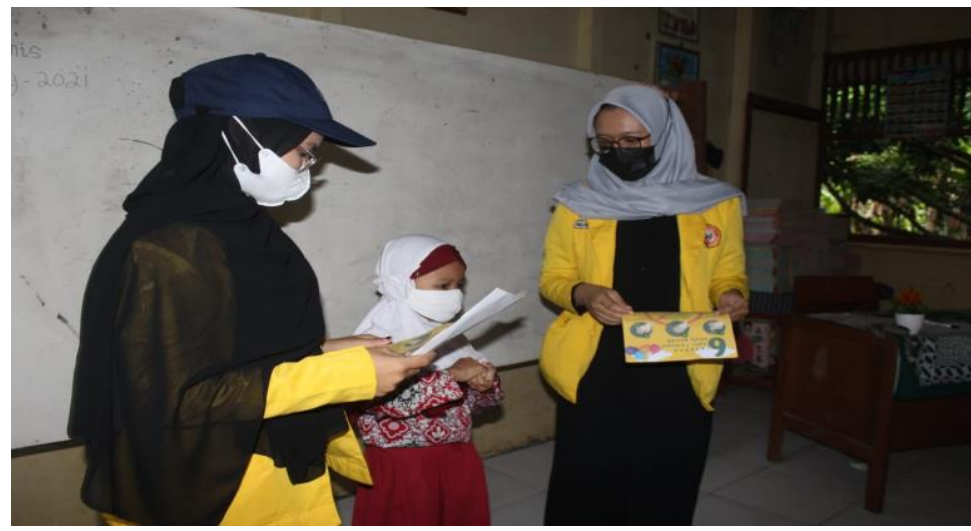

Gambar 2 : Contoh praktek mencuci tangan yang baik dan benar dengan salah satu murid SDN Cabi

Kegiatan di atas adalah bentuk sosialisasi kepada murid-murid yang ada di SDN Cabi. Dengan memilih salah satu murid dan mencotohkannya di depan murid-murid yang lain agar tahu tata cara mencuci tangan yang baik dan benar serta bisa dipraktekkan langsung ketika ingin memasuki ruang kelas, bahkan bisa dipraktekkan langsung dalam kehidupan sehari-hari.

\section{KESIMPULAN}

Program sosialisasi dan edukasi pencegahan Covid-19 kepada siswa SDN Cabi merupakan bentuk upaya menciptakan situasi yang kondusif di era new normal, guna mengantisipasi terhadap indikasi tingkat resiko yang tidak aman pada zona hijau. Sehingga, kegiatan pembelajaran dapat dilaksanakan secara tatap muka dengan membentuk kebiasaan baru melalui penerapan protokol kesehatan. Rencana pemerintah untuk mengadakan belajar tatap muka sangat dipengaruhi oleh kesuksesan dan kepedulian masyarakat dalam menekan penyebaran Covid-19. Kegiatan ini dilaksanakan secara bertahap mulai dari kegiatan sosialisasi dengan metode pengajaran melalui media mind mapping. Selanjutnya, kegiatan melalui simulasi atau praktik langsung ke siswa. Kegiatan sosialisasi dan edukasi pencegahan Covid-19 ini merupakan kegiatan pengabdian kepada masyarakat yang bertujuan agar siswa Sekolah Dasar mengerti dan memahami tentang Covid-19 serta cara pencegahannya maupun pentingnya menerapkan protokol kesehatan. Siswa Sekolah Dasar perlu memahami hal ini agar dapat turut serta dalam upaya pencegahan penularan Covid-19. Mengingat perkembangan saat ini, Covid-19 ini tidak lagi menyerang kelompok dewasa dan lansia saja, namun juga anak-anak. Tingginya kesadaran warga sekolah terhadap penggunaan protokol kesehatan di lingkungan sekolah akan berdampak positif pada penerapan protokol kesehatan di lingkungan sekolah tersebut. Dengan demikian, lingkungan sekolah menjadi tempat yang aman bagi warga sekolah untuk melakukan kegiatan belajar mengajar di kelas.

\section{UCAPAN TERIMAKASIH}

Ucapan terima kasih disampaikan kepada FISIP Universitas Lambung Mangkurat yang telah mendukug berlangsungnya kegiatan ini.

\section{REFERENSI}

Anita, I., Hermawan, L., Junaedi, D., Buana, U. L., \& Buana, U. L. (2020). Penerapan Protokol Kesehatan alam Upaya Sekolah Bebas Covid-19. 2(2).

Anugrahana, A. (2020). Hambatan, Solusi dan Harapan: Pembelajaran Daring Selama Masa Pandemi Covid-19 Oleh Guru Sekolah Dasar. Scholaria: Jurnal Pendidikan Dan Kebudayaan, 10(3), 282-289. https://doi.org/10.24246/j.js.2020.v10.i3.p282-289

Kemdikbud. (2020). Panduan Penyelenggaraan Pembelajaran di Masa Pandemi COVID-19. Kemendikbud, 2019, 1-58. https://www.kemdikbud.go.id/main/blog/202 0/06/buku-saku-panduan-pembelajaran-dimasapandemi-covid19 
Syah, D. Z. R., Utari, D., \& ... (2020). Edukasi Penerapan Protokol Kesehatan Penyelenggaraan Kegiatan Pada Masa Pandemi Covid 19 Di Tpq Masjid Awalulmu'Minin 2(2), $28-33$. http://jurnal.poltekkeskhjogja.ac.id/index.php/jpmkh/article/view/408

Wijanarko, A., Setiawan, Y., Efendi, R., Supratman, J. W., Limun, K., \& Bengkulu, K. (2021). Optimalisasi Pelaksanaan Penerapan Protokol Kesehatan Penanganan Covid-19 Pada Fase New Normal Melalui Literasi Media Di Sdit Iqra 1 Bengkulu. Abdi Reksa, 2(1), 51-58. www.ejournal.unib.ac.id/index.php/abdireksa 